\title{
Immediate and delayed effects of nitrogen dioxide exposure at an ambient level on bronchial responsiveness to histamine in subjects with asthma
}

\author{
V. Strand*, P. Salomonsson*, J. Lundahl**, G. Bylin*
}

Immediate and delayed effects of nitrogen dioxide exposure at an ambient level on bronchial responsiveness to histamine in subjects with asthma. V. Strand, P. Salomonsson, J. Lundahl, G. Bylin. @ERS Journals Ltd 1996.

ABSTRACT: The time-kinetics of $\mathrm{NO}_{2}$ induced effects on bronchial responsiveness are poorly known as most observations have been made shortly after exposure. The aim of this study was to measure nonspecific bronchial responsiveness, lung function and inflammatory markers at different times after $\mathrm{NO}_{2}$ exposure in asthmatics.

Nineteen subjects with mild asthma were exposed to either purified air or 488 $\mu \mathrm{g} \cdot \mathrm{m}^{-3}(0.26 \mathrm{ppm}) \mathrm{NO}_{2}$ for $30 \mathrm{~min}$ during intermittent exercise. Airway responsiveness to histamine, specific airway resistance $(\mathrm{s} R$ aw) and thoracic gas volume (TGV) were measured $30 \mathrm{~min}, 5 \mathrm{~h}, 27 \mathrm{~h}$ and 7 days after exposure. Peripheral blood inflammatory mediators and the expression of an adhesion molecule, (Mac1) on granulocytes, were analysed $30 \mathrm{~min}$ and $27 \mathrm{~h}$ after exposure.

Bronchial responsiveness to histamine was significantly increased $5 \mathrm{~h}$ after $\mathrm{NO}_{2}$ exposure when compared to air (median provocative dose of histamine required to cause $100 \%$ increase of $s R a w\left(\left(P D_{s} R a w, 100 \%\right) 110 \mu g\right.$ after $\mathrm{NO}_{2}$ exposure vs $203 \mu \mathrm{g}$ on air). There was a tendency for an increase after $30 \mathrm{~min}$, which was nonsignificant (median PDsRaw, $100 \% 100$ vs $153 \mu \mathrm{g}$ ). $\mathrm{NO}_{2}$ exposure did not affect sRaw, but TGV was significantly reduced after exposure. We found an increased expression of Mac-1 on granulocytes 30 min after $\mathrm{NO}_{2}$ exposure when compared to pre-exposure values. No effect was seen on tryptase, eosinophil cationic protein (ECP), or myeloperoxidase (MPO).

These results suggest that exposure to an ambient level of $\mathrm{NO}_{2}$ causes a delayed effect on bronchial responsiveness in asthmatics. The increased expression of an adhesion molecule in peripheral blood may indicate a $\mathrm{NO}_{2}$-induced priming of human granulocytes.

Eur Respir J., 1996, 9, 733-740

Nitrogen dioxide is a well-known airways irritant at high concentrations, but whether exposure to $\mathrm{NO}_{2}$ at ambient levels (below $1,000 \mu \mathrm{g} \cdot \mathrm{m}^{-3}$ ) affects the airways has been a matter of debate. Nonspecific bronchial responsiveness has been reported to increase in asthmatics after exposure to $\mathrm{NO}_{2}$ concentrations well below 1,000 $\mu \mathrm{g} \cdot \mathrm{m}^{-3}$ in several studies $[1,2]$, although no effect was seen in others [3, 4]. FolinsBeE [5] recently reported, in a meta-analysis of 20 studies of asthmatics and five of normal subjects, a statistically significant increase in bronchial responsiveness on exposure to $\geq 200 \mu \mathrm{g} \cdot \mathrm{m}^{-3} \mathrm{NO}_{2}$ in asthmatics and to $\geq 1,900 \mu \mathrm{g} \cdot \mathrm{m}^{-3}$ in normals. There is, thus, reason to believe that $\mathrm{NO}_{2}$ at ambient concentrations might increase bronchial responsiveness, at least in subjects with asthma.

Earlier studies of $\mathrm{NO}_{2}$ effects have focused on bronchial responsiveness within the first hour after the end of exposure. However, the toxic effects of high concentrations of $\mathrm{NO}_{2}$, as seen in industrial gas accidents, occurred several hours after exposure [6]. RASMUSSEN et al. [7] reported on delayed effects of $\mathrm{NO}_{2}$ on alveolar permeability in healthy subjects. Furthermore, in bronchoalveolar lavage (BAL) studies, SANDSTRÖM et al. [8]
*Dept for Respiratory and Allergic Diseases, Huddinge University Hospital, Huddinge, Sweden. **Dept of Clinical Immunology, Karolinska Hospital, Stockholm, Sweden.

\section{Correspondence: V. Strand}

Dept for Respiratory and Allergic Diseases Huddinge University Hospital S-14186 Huddinge

Sweden

\section{Keywords: Asthma}

bronchial responsiveness

inflammatory markers

lung function

Received: August 191994

Accepted after revision December 101995

This study was supported by grants from the Environmental Fund of the Stockholm County Council, The Stockholm City and Stockholm County local branches of the Swedish Association against Asthma and Allergy and the Swedish Building Research Council.

found a maximal influx of inflammatory cells in bronchial lavage fluid as late as $8 \mathrm{~h}$ after $\mathrm{NO}_{2}$ exposure. Thus, it is of interest to know whether $\mathrm{NO}_{2}$ also has a delayed effect on bronchial responsiveness.

The aim of this study was to investigate the time-kinetics of $\mathrm{NO}_{2}$ induced effects on nonspecific bronchial responsiveness and lung function in asthmatics. Furthermore, expression of an adhesion molecule Mac-1, on granulocytes and inflammation markers in peripheral blood was studied in order to find signs of a possible $\mathrm{NO}_{2}$ induced inflammatory reaction.

\section{Material and methods}

\section{Subjects}

Nineteen subjects, age 20-48 yrs, with mild asthma, participated in the study. Anthropomethric and clinical data are presented in table 1 . The inclusion criterion was asthma with reversible attacks of dyspnoea and bronchial hyperresponsiveness to histamine (threshold 
Table 1. - Anthropometric and clinical data

\begin{tabular}{|c|c|c|c|c|c|c|c|c|c|}
\hline $\begin{array}{l}\text { Subj } \\
\text { No. }\end{array}$ & $\begin{array}{l}\text { Age } \\
\text { yrs }\end{array}$ & Sex & $\begin{array}{l}\text { Height } \\
\mathrm{cm}\end{array}$ & $\begin{array}{c}\text { Weight } \\
\mathrm{kg}\end{array}$ & $\begin{array}{c}\text { Asthma } \\
\text { duration } \\
\text { yrs }\end{array}$ & $\begin{array}{c}\text { Positive } \\
\text { skin-prick test } \\
\geq 2+\end{array}$ & $\begin{array}{c}\text { Smoking } \\
\text { status }\end{array}$ & $\begin{array}{l}\mathrm{s} R \text { aw } \\
\mathrm{cmH} \mathrm{O}_{2} \mathrm{O} \cdot \mathrm{s}^{-1}\end{array}$ & $\begin{array}{c}\mathrm{VC} \\
\% \text { pred }\end{array}$ \\
\hline 1 & 20 & $\mathrm{~F}$ & 168 & 73 & 7 & B, T, D, C & LNS & 4.08 & 129 \\
\hline 2 & 33 & $\mathrm{M}$ & 178 & 78 & 12 & $\mathrm{~B}, \mathrm{~T}, \mathrm{M}, \mathrm{R}, \mathrm{Mi}$ & ES & 3.78 & 113 \\
\hline 3 & 32 & M & 191 & 77 & 29 & $\mathrm{~B}, \mathrm{~T}, \mathrm{M}, \mathrm{D}, \mathrm{C}, \mathrm{Mo}$ & LNS & 3.86 & 104 \\
\hline 4 & 32 & $\mathrm{~F}$ & 161 & 52 & 9 & $\mathrm{Mi}$ & LNS & 3.75 & 99 \\
\hline 5 & 36 & M & 194 & 90 & 2 & $\mathrm{D}, \mathrm{C}, \mathrm{H}$ & ES & 3.21 & 112 \\
\hline 6 & 21 & $\mathrm{M}$ & 175 & 71 & 18 & $\mathrm{D}, \mathrm{C}, \mathrm{H}$ & LNS & 3.87 & 104 \\
\hline 7 & 40 & M & 172 & 67 & 18 & $\mathrm{~B}, \mathrm{~T}, \mathrm{D}, \mathrm{C}, \mathrm{Mo}$ & ES & 6.66 & 122 \\
\hline 8 & 23 & $\mathrm{~F}$ & 173 & 105 & 6 & $\mathrm{C}$ & LNS & 5.24 & 113 \\
\hline 9 & 40 & M & 179 & 77 & 9 & $\mathrm{D}, \mathrm{C}$ & ES & 3.39 & 114 \\
\hline 10 & 45 & $\mathrm{~F}$ & 162 & 60 & 6 & $\mathrm{~T}$ & $\mathrm{ES}$ & 5.36 & 110 \\
\hline 11 & 22 & $\mathrm{~F}$ & 158 & 61 & 3 & $\mathrm{~B}, \mathrm{~T}, \mathrm{C}$ & LNS & 6.13 & 132 \\
\hline 12 & 39 & M & 174 & 80 & 5 & $\mathrm{~B}, \mathrm{D}, \mathrm{Mo}$ & ES & 4.05 & 82 \\
\hline 13 & 26 & $\mathrm{~F}$ & 160 & 54 & 1 & $*$ & LNS & 5.36 & 98 \\
\hline 14 & 26 & $\mathrm{~F}$ & 177 & 76 & 11 & $\mathrm{~B}, \mathrm{C}, \mathrm{H}$ & LNS & 6.17 & 111 \\
\hline 15 & 37 & M & 177 & 68 & 11 & C & LNS & 4.96 & 99 \\
\hline 16 & 48 & $\mathrm{~F}$ & 152 & 70 & 29 & B, T, D, C & LNS & 5.65 & 99 \\
\hline 17 & 33 & $\mathrm{~F}$ & 170 & 82 & 33 & $\mathrm{~B}, \mathrm{~T}, \mathrm{M}, \mathrm{D}, \mathrm{C}$ & ES & 7.72 & 110 \\
\hline 18 & 41 & M & 178 & 70 & 39 & $\mathrm{~B}, \mathrm{~T}, \mathrm{D}, \mathrm{C}, \mathrm{H}$ & ES & 5.28 & 123 \\
\hline 19 & 23 & $\mathrm{~F}$ & 164 & 60 & 7 & $*$ & ES & 4.20 & 101 \\
\hline Mean & 32 & & 172 & 72 & 13 & & & 4.88 & 109 \\
\hline SD & 9 & & 11 & 13 & 11 & & & 1.23 & 12 \\
\hline
\end{tabular}

Subj: subject; M: male; F: female; B: birch, T: Timothy; D: dog; C: cat, M: Mugwort; R: rabbit; Mi: house dust mite; Mo: mould; H: horse; ES: ex-smoker; LNS: lifetime nonsmoker; sRaw: specific airway resistance; VC: vital capacity; \% pred: percentage of predicted value.

dose $\leq 660 \mu \mathrm{g}$ histamine causing a doubling of the specific airway resistance, $\mathrm{s} R \mathrm{aw}, 100 \%)$. Lung function expressed as $s R$ aw was within normal range $\left(<8.0 \mathrm{cmH}_{2} \mathrm{O} \cdot \mathrm{s}^{-1}\right)$ [9]. Seventeen patients had an immunoglobulin E (IgE) mediated allergy according to standard skin-prick test. The pollen allergic patients were not exposed during pollen season, and patients sensitive to animal dander did not have pets in their homes.

All subjects had occasional symptoms of asthma and then used a bronchodilating beta ${ }_{2}$-agonist. Two subjects used inhaled sodium cromoglycate periodically but not during study. No oral or inhaled steroid treatment was used. All subjects were nonsmokers, 10 were lifetime nonsmokers and 9 had been ex-smokers for at least 2 yrs.

The study was approved by the Ethics Committee at Huddinge University Hospital.

\section{Study design}

The design of the study is shown in figure 1 . The subjects were exposed to purified air or $488 \pm 13 \mu \mathrm{g} \cdot \mathrm{m}^{-3}$ $\mathrm{NO}_{2}($ mean $\pm \mathrm{SD})$ in an exposure chamber for $30 \mathrm{~min}$ on two separate days. The order of exposure was randomized (8 exposed first to $\mathrm{NO}_{2}, 11$ first to air) and singleblind. The interval between exposures was 3-4 weeks. The exposures to air and $\mathrm{NO}_{2}$ were performed at 8.30 or 9.30 a.m., and at the same time for each subject.

Baseline airway resistance, thoracic gas volume and bronchial responsiveness to histamine were measured on a separate screening day. On this occasion, the subject gave informed consent to participate in the study.

The experiment consisted of a 30 min exposure $\left(\mathrm{NO}_{2}\right.$ or air) with intermittent exercise followed by histamine inhalation tests at $30 \mathrm{~min}, 5 \mathrm{~h}, 27 \mathrm{~h}$ and 7 days after the end of exposure. Lung function was measured before and during exposure and before the histamine challenge. Blood samples were drawn before, $30 \mathrm{~min}$ and $27 \mathrm{~h}$ after exposure.

The procedure, in more detail, was as follows. After arrival at the laboratory, the subject rested for $15 \mathrm{~min}$. A sample of venous blood was then drawn for analyses of eosinophilic cationic protein (ECP), myeloperoxidase (MPO), tryptase and Mac-1 expression on granulocytes. Specific airway resistance (sRaw) and thoracic gas volume (TGV) were measured and the subject rested for 10

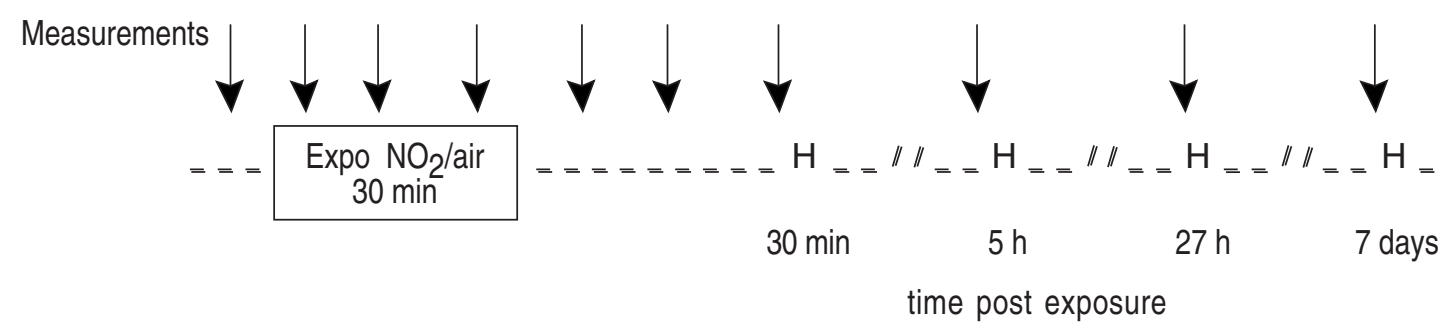

Fig. 1. - Study design. Expo: exposure; $\downarrow$ : airway resistance and lung volume measurement; H: histamine inhalation challenge. 
min. The subject then entered the exposure chamber and sat resting or cycling on an ergometer bicycle $(2 \times 7 \mathrm{~min}$ periods; from 6th to 13 th and 17 th to 24 th minute of exposure). The workload on the bicycle was $52 \pm 21$ and $51 \pm 19 \mathrm{~W}$ (mean $\pm \mathrm{SD})$ during air and $\mathrm{NO}_{2}$, respectively, and the corresponding values for the subjects' ventilation $35 \pm 8$ and $33 \pm 5 \mathrm{~L} \cdot \mathrm{min}^{-1}$. sR aw and TGV were measured at 4,15 and $30 \mathrm{~min}$ of exposure in a body plethysmograph located in the exposure chamber. The subject was interviewed concerning symptoms after 3 and $26 \mathrm{~min}$ exposure, with the help of a questionnaire.

Ten and $20 \mathrm{~min}$ after the end of exposure, lung function was measured again. Thirty minutes after exposure, a second blood sample was drawn and a histamine inhalation test started. Five hours after the end of exposure a second histamine bronchial provocation test was performed. The following day, the subject returned for a third histamine challenge and on that occasion a third blood sample was drawn. A final bronchial provocation test was performed 7 days after exposure, and on this occasion the subject was interviewed about complaints during the past week.

\section{Lung function measurements}

Airway resistance (Raw) and TGV were measured in a body plethysmograph (Cardio-Pulmonary Instruments, Houston, TX, USA; Model 2000 TB, constant volume type). Recordings of Raw and TGV were made according to Du BoIs and co-workers [10,11]. Gas flow and box pressure, as well as mouth pressure and box pressure, were recorded on an $\mathrm{x}-\mathrm{y}$ recorder (Bryans 50000).

The gas flow/box pressure slopes were measured between gas flow +0.5 and $-0.5 \mathrm{~L} \cdot \mathrm{s}^{-1}$ (expiration - inspiration) as a mean of 2-3 slopes. The mouth/box pressure slopes were measured between the endpoints, again as the mean of 2-3 curves. All panting manoeuvres were made at about $1 \mathrm{~Hz}$, the subject being guided by a metronome. Tidal ventilation was measured using a Fleisch pneumotachograph connected to a transducer (Mercury Electronics, Glasgow, Scotland, UK).

\section{Bronchial challenge}

Histamine provocation tests were performed by using an automatic, inhalation synchronized, dosimeter jet nebulizer (Spira Elektro 2; Respiratory Care Center, Hameenlinna, Finland) with adjustable aerosol delivery time [12]. With this equipment, the start of the aerosolization was determined by a threshold volume of inspiration. Inhalation flow, number of nebulizations and the volume of each inhalation were displayed. The nebulization time was set to $0.5 \mathrm{~s}$ and the aerolization started after an inspired volume of $100 \mathrm{~mL}$ and ended within tidal volume. The flow rate was $0.5 \mathrm{~mL} \cdot \mathrm{min}^{-1}$. Three concentrations of histamine diphosphate were used, 1,8 and $64 \mathrm{mg} \cdot \mathrm{mL}^{-1}$. At each concentration, 2, 4 and 8 breaths were taken. After measuring baseline $\mathrm{s} R$ aw the subject inhaled doubling doses of histamine from an initial dose of 13.75 $\mu \mathrm{g}$ until $100 \%$ increase in sRaw was reached. sRaw and TGV were measured 3 min after each dose. Threshold provocative dose of histamine required to cause $100 \%$ increase of $\mathrm{s} R$ aw (PDsRaw,100\%) was calculated by linear interpolation on the dose-effect curve.

\section{Questionnaire}

After 3 and 26 min of exposure, the subject was interviewed by means of a questionnaire used previously by our group [13] comprising 16 questions concerning respiratory symptoms and annoying perceptions in the chamber, estimated by a scale with range $1-7$. When returning after 7 days, the subject was asked to report symptoms within $24 \mathrm{~h}$ after exposure, within 7 days after exposure, and during the period between the two exposures.

\section{Blood samples}

Samples for ECP, MPO and tryptase were drawn immediately before, $30 \mathrm{~min}$ and $27 \mathrm{~h}$ after the end of exposure. ECP, MPO and tryptase were analysed by means of radioimmunoassays [14, 15]. Ethylenediamine tetraacetic acid (EDTA) blood was collected for flow cytometric immunoassay of Mac-1 expression from the subjects at the same times as above. The blood samples were haemolysed in $100 \mu \mathrm{L}$ portions by dilution in $2 \mathrm{~mL} 4^{\circ} \mathrm{C}$ $\mathrm{NH}_{4} \mathrm{Cl}$-EDTA "lysing reagent" (Ortho Diagnostics Systems, Westwood, NJ, USA). After 5 min incubation at $15^{\circ} \mathrm{C}$, the leucocytes were centrifugated at $300 \times \mathrm{g}$ for 5 min followed by one wash in $4^{\circ} \mathrm{C} 0.15 \mathrm{M}$ phosphatebuffered saline (PBS) supplemented with $0.1 \mathrm{mM}$ EDTA and $0.02 \%$ Na-azide (PBS-EDTA).

Mac-1 expression on granulocytes was analysed routinely [16, 17] by adding $10 \mu \mathrm{L}$ phycoerythrin (PE)conjugated monoclonal anti-CD 11b/CD 18 (Becton and Dickinson Immunocytometry Systems, Mountain View, CA, USA) to leucocyte pellets. The suspensions were incubated at $4^{\circ} \mathrm{C}$ for $30 \mathrm{~min}$ followed by two washes in $4^{\circ} \mathrm{C}$ PBS-EDTA. The leucocytes were resuspended with $1 \mathrm{~mL}$ PBS-EDTA. Isotype matched control antibodies (PE-conjugated mouse immunoglobulin $\mathrm{G}_{2}\left(\mathrm{IgG}_{2}\right)$; Becton and Dickinson Immunocytometry Systems, Mountain View, CA, USA) were used to define the cut-off for positive fluorescence, which was the 99th percentile of the distribution of the cells labelled with respective control antibody. EDTA-blood from healthy nonallergic blooddonors was run parallel as control samples.

The leucocytes were finally examined in an Ortho Spectrum III Flow Cytofluorometer (Ortho Diagnostics Systems, Westwood, MA, USA). A discrimination frame was placed around the granulocyte field. The amount of surface antigen was described by the mean fluorescence intensity (MFI) of the cell population within the field.

\section{Gas dilution and exposure system}

$\mathrm{NO}_{2}$ gas, kept in a gas bottle (Alfax, approx 8,000 $\mathrm{mg} \cdot \mathrm{m}^{-3} \mathrm{NO}_{2}$ ) was diluted in two steps to a final concentration of about $500 \mu \mathrm{g} \cdot \mathrm{m}^{-3} \mathrm{NO}_{2}$ and fed into the exposure chamber (volume $7 \mathrm{~m}^{3}$ ). The gas dilution and exposure system has been presented in more detail previously [2]. 


\section{Chemical analyses}

$\mathrm{NO}_{2}$ concentrations in the exposure chamber were measured with a chemiluminescence instrument (Monitor Labs Nitrogen Oxides Analyser, Model 8440). For calibration, a $\mathrm{NO}_{2}$ permeation tube and $\mathrm{NO}$ calibration gas (Monitor Labs 8500 Calibrator; AGA Special Gas, 100 $\mathrm{ppm} \cdot \mathrm{m}^{-3} \mathrm{NO}$ ) were used. A calibration procedure was run daily.

The subject's individual exposure to $\mathrm{NO}_{2}$ during the week following the exposure experiment in the laboratory was measured with a personal, passive (filter badge) sampler (Toyo Roshi Kaisha Ltd, Japan; Yanagisawa and Nishimura 1982). The sampler was carried by the subject for 1 week, pinned to the clothes (at the left shoulder) during the daytime and lying on a table in the bedroom at night. The analytical technique as well as the accuracy and reproducibility of the measurements with the sampler have been presented in detail previously [18].

\section{Exposure data}

$\mathrm{NO}_{2}$ concentrations in the exposure chamber were measured in the breathing zone of the subject. The mean \pm SD concentration was $488 \pm 13 \mu \mathrm{g} \cdot \mathrm{m}^{-3}$ (range $464-515 \mu \mathrm{g} \cdot \mathrm{m}^{-3}$ ). During exposure to filtered air, the $\mathrm{NO}_{2}$ concentration was below $10 \mu \mathrm{g} \cdot \mathrm{m}^{-3}$. The temperature in the exposure chamber was $25.2 \pm 0.6^{\circ} \mathrm{C}$ (mean \pm SD) during air and $25.5 \pm 0.6^{\circ} \mathrm{C}$ during $\mathrm{NO}_{2}$ exposure. The corresponding values for relative humidity was $56 \pm 14$ and $52 \pm 12 \%$.

a)

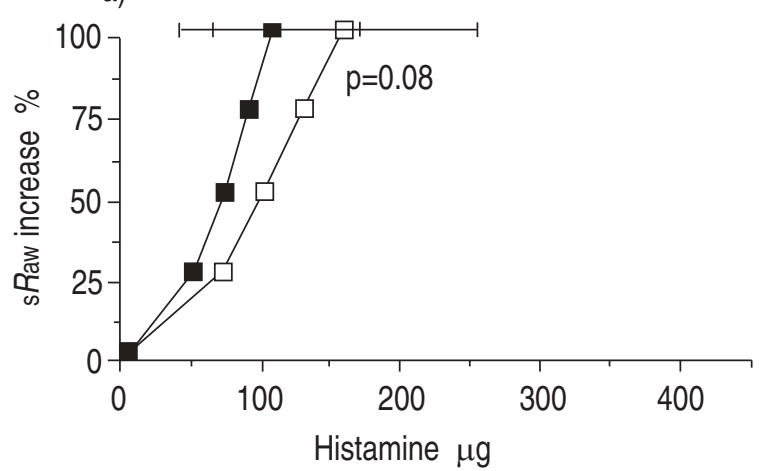

c)

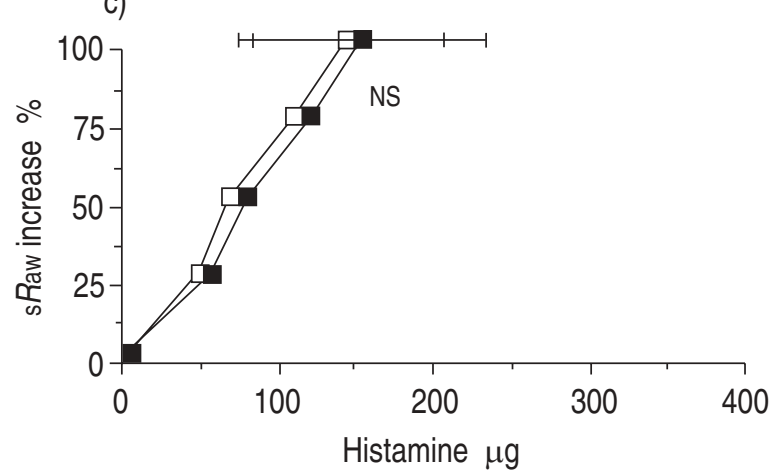

During the week following the exposure experiment, the exposure to $\mathrm{NO}_{2}$ in ambient air was $11 \pm 7 \mu \mathrm{g} \cdot \mathrm{m}^{-3}$ (mean \pm SD) (range 14-37 $\mu \mathrm{g} \cdot \mathrm{m}^{-3}$ ) after exposure to $\mathrm{NO}_{2}$ and $11 \pm 4(5-22) \mu \mathrm{g} \cdot \mathrm{m}^{-3}$ after air exposure.

\section{Statistics}

Data obtained after $\mathrm{NO}_{2}$ and filtered air were compared at the different time-points $(30 \mathrm{~min}, 5$ and $27 \mathrm{~h}$, and 7 days) by the nonparametric Wilcoxon sign rank test. Probability values of less than $5 \%$ were considered to be significant.

\section{Results}

\section{Bronchial responsiveness}

All subjects but one completed all the measurements of lung function and bronchial responsiveness. Bronchial responsiveness could not be measured 5 and $27 \mathrm{~h}$ after exposure to $\mathrm{NO}_{2}$ in one subject (No. 8) because of symptoms of asthma.

The mean increases of $s R$ aw, in response to inhaled histamine after exposure to $\mathrm{NO}_{2}$ and filtered air, respectively, are shown in figure 2. The individual PDsRaw,100\% at the different times after exposure to $\mathrm{NO}_{2}$ or filtered air are shown in table 2.

PDsRaw, $100 \%$ for histamine tended to decrease in the group 30 min after $\mathrm{NO}_{2}$ exposure, 100 vs $153 \mu \mathrm{g}$ after
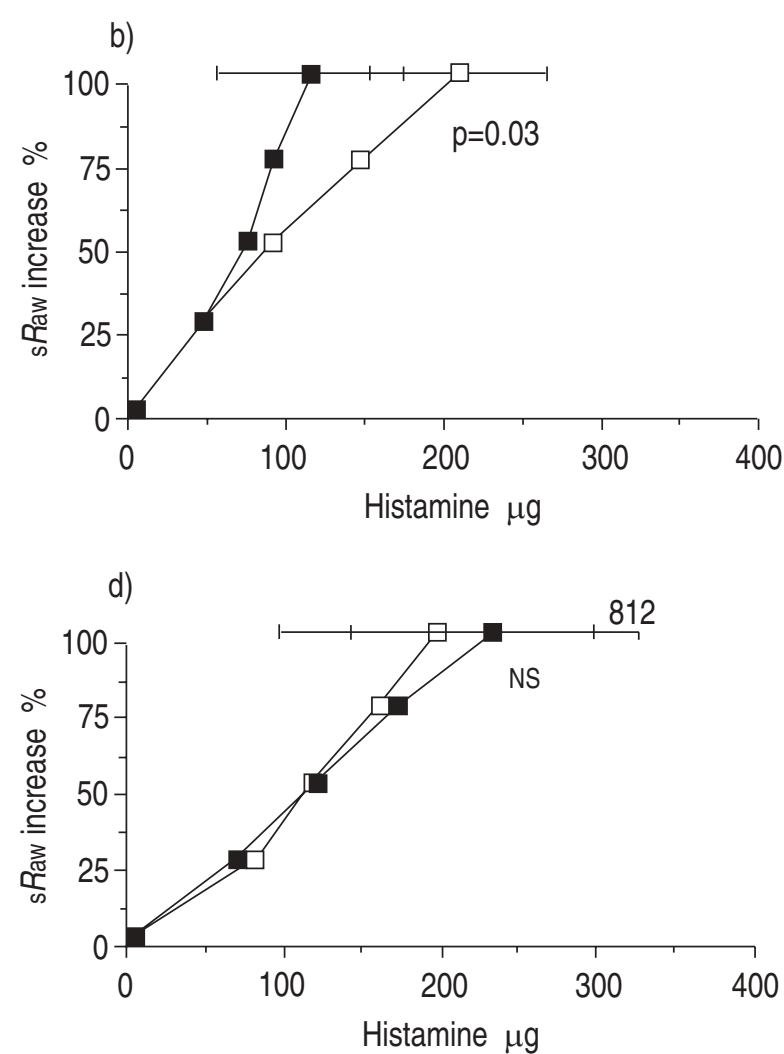

Fig. 2. - Bronchial responsiveness. Increase $(\%)$ of specific airway resistance $(\mathrm{s} R$ aw) in response to inhaled histamine $(\mu \mathrm{g})$ after exposure to 488 $\mu \mathrm{g} \cdot \mathrm{m}^{-3} \mathrm{NO}_{2}$ and filtered air. Median values and 25th and 75th percentile are presented. a) 30 min after exposure (n=19); b) $5 \mathrm{~h}$ after exposure $(\mathrm{n}=18)$; c) $27 \mathrm{~h}$ after exposure $(\mathrm{n}=18)$; d) 7 days after exposure $(\mathrm{n}=19)$. ———: $: \mathrm{s} R$ aw Air; — $: \mathrm{s} R$ aw $\mathrm{NO}_{2}$. 
air (median) but the decrease was not significant ( $\mathrm{p}=0.08)$. Five hours after exposure, the difference in histamine response between $\mathrm{NO}_{2}$ and air was significant, (median PDsRaw, 100\% 110 vs $203 \mu \mathrm{g}$; $\mathrm{p}=0.03$ ). There were no significant differences in response to histamine $27 \mathrm{~h}$ or 7 days after exposure.

The mean decrease among the 11 subjects reacting with a lower threshold dose $5 \mathrm{~h}$ after $\mathrm{NO}_{2}$ corresponded to 0.83 doubling doses of histamine. Three of these subjects decreased their threshold dose with more than one doubling dose.

\section{Airway resistance and lung volume}

sRaw was equally increased by exercise during exposure to air $(\mathrm{p}=0.001)$ and $\mathrm{NO}_{2}(\mathrm{p}=0.001)$ (fig. 3). TGV was not significantly affected during exposure, but from $20 \mathrm{~min}$ after exposure and onwards lung volume was consistently lower after exposure to $\mathrm{NO}_{2}$ compared to air, although statistically significant differences were only seen $20 \mathrm{~min}(\mathrm{p}=0.001)$ and 7 days $(\mathrm{p}=0.02)$ after exposure (fig. 4). The change was maximal 20 min after exposure, with a $0.37 \mathrm{~L}$ mean reduction.

\section{Inflammatory cells and mediators}

An increased expression of Mac-1 was found on granulocytes $30 \mathrm{~min}$ after $\mathrm{NO}_{2}$-exposure when compared to pre-exposure values $(13.4 \pm 4.6$ vs $10.9 \pm 4.7 \mathrm{MFI} ; \mathrm{p}=0.01$;

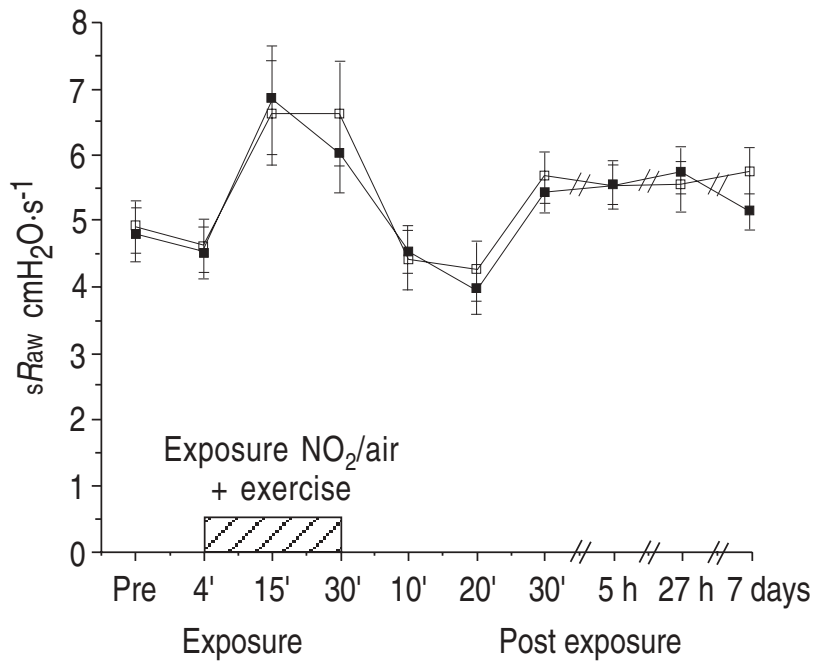

Fig. 3. - Specific airway resistance ( $\mathrm{s} R \mathrm{aw}$ ). Changes during and after

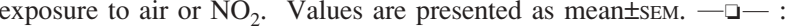
sRaw Air; —- : $\_$aw $\mathrm{NO}_{2}$.

$\mathrm{n}=15$; mean $\pm \mathrm{SD}$ ) (fig. 5). The Mac-1 expression was reversed to pre-exposure values $27 \mathrm{~h}$ after exposure $(10.7 \pm 2.8$ vs 10.9 \pm 4.7 MFI; NS; $\mathrm{n}=15$ ).

There were no significant differences in ECP, MPO and tryptase levels when comparing pre- and post-exposure values. Because of inappropriate technical handling of the early samples, only the analyses of 12 subjects were complete.

Table 2. - PDsRaw, $100 \%$ as a measure of bronchial responsiveness: individual dose of histamine $(\mu \mathrm{g})$ required for $100 \%$ increase of sRaw at inclusion, $30 \mathrm{~min}, 5 \mathrm{~h}, 27 \mathrm{~h}$ and 7 days after exposure to air or $488 \mu \mathrm{g} \cdot \mathrm{m}^{-3} \mathrm{NO}_{2}$ and difference between air and $\mathrm{NO}_{2}$ values

\begin{tabular}{|c|c|c|c|c|c|c|c|c|c|c|c|c|c|}
\hline \multirow{2}{*}{$\begin{array}{l}\text { Subj } \\
\text { No. }\end{array}$} & \multirow[t]{2}{*}{ Inclusion } & \multicolumn{3}{|c|}{$30 \mathrm{~min}$} & \multicolumn{3}{|c|}{$5 \mathrm{~h}$} & \multicolumn{3}{|c|}{$27 \mathrm{~h}$} & \multicolumn{3}{|c|}{7 days } \\
\hline & & Air & $\mathrm{NO}_{2}$ & $\Delta$ & Air & $\mathrm{NO}_{2}$ & $\Delta$ & Air & $\mathrm{NO}_{2}$ & $\Delta$ & Air & $\mathrm{NO}_{2}$ & $\Delta$ \\
\hline 1 & 512 & 355 & 473 & -118 & 274 & 179 & 95 & 208 & 190 & 19 & 928 & 404 & 524 \\
\hline 2 & 512 & 135 & 346 & -211 & 320 & 131 & 188 & 213 & 112 & 100 & 212 & 330 & -118 \\
\hline 3 & 194 & 94 & 62 & 32 & 25 & 25 & 0 & 59 & 129 & -70 & 88 & 170 & -83 \\
\hline 4 & 304 & 804 & 540 & 264 & 1149 & 787 & 362 & 1760 & 1067 & 693 & 812 & 498 & 314 \\
\hline 5 & 124 & 577 & 71 & 506 & 9 & 102 & -93 & 486 & 148 & 338 & 141 & 292 & -152 \\
\hline 6 & 121 & 40 & 69 & -29 & 60 & 26 & 34 & 26 & 60 & -35 & 63 & 61 & 2 \\
\hline 7 & 165 & 148 & 146 & 2 & 203 & 102 & 101 & 140 & 49 & 91 & 282 & 233 & 48 \\
\hline 8 & 49 & 49 & 49 & 0 & 59 & - & - & 46 & - & - & 35 & 39 & -3 \\
\hline 9 & 249 & 259 & 288 & -29 & 365 & 110 & 255 & 97 & 366 & -270 & 267 & 504 & -237 \\
\hline 10 & 495 & 370 & 421 & -51 & 796 & 534 & 262 & 534 & 417 & 116 & 888 & 711 & 177 \\
\hline 11 & 220 & 104 & 69 & 35 & 217 & 110 & 107 & 153 & 243 & -90 & 200 & 228 & -27 \\
\hline 12 & 558 & 1350 & 908 & 442 & 848 & 945 & -96 & 275 & 221 & 54 & 1610 & 2046 & -436 \\
\hline 13 & 107 & 66 & 25 & 42 & 37 & 58 & -21 & 78 & 79 & -1 & 81 & 80 & 1 \\
\hline 14 & 174 & 207 & 104 & 103 & 353 & 186 & 166 & 371 & 153 & 218 & 186 & 73 & 114 \\
\hline 15 & 143 & 171 & 41 & 130 & 45 & 50 & -4 & 107 & 71 & 36 & 160 & 147 & 12 \\
\hline 16 & 49 & 153 & 86 & 67 & 57 & 43 & 15 & 29 & 35 & -7 & 99 & 117 & -18 \\
\hline 17 & 61 & 51 & 46 & 5 & 55 & 73 & -18 & 37 & 211 & -174 & - & 88 & - \\
\hline 18 & 630 & 574 & 507 & 67 & 461 & 429 & 33 & 241 & 715 & -474 & 1613 & 446 & 1167 \\
\hline 19 & 94 & 111 & 100 & 11 & 90 & 117 & -28 & 71 & 99 & -28 & 108 & 100 & 8 \\
\hline Median & 174 & 153 & 100 & & 203 & 110 & & 140 & 151 & & 193 & 228 & \\
\hline $\mathrm{P} 25$ & 107 & 94 & 62 & & 55 & 58 & & 59 & 79 & & 99 & 88 & \\
\hline P75 & 495 & 370 & 421 & & 365 & 186 & & 275 & 243 & & 812 & 446 & \\
\hline \multirow[t]{2}{*}{ Mean } & 251 & 296 & 229 & & 285 & 223 & & 260 & 243 & & 432 & 346 & \\
\hline & & \multicolumn{3}{|c|}{$\mathrm{NS}(\mathrm{p}=0.08)$} & \multicolumn{3}{|c|}{$\mathrm{p}=0.03$} & \multicolumn{3}{|c|}{ NS $(p=0.6)$} & \multicolumn{3}{|c|}{$\mathrm{NS}(\mathrm{p}=0.7)$} \\
\hline
\end{tabular}

$\Delta$ : difference between air and $\mathrm{NO}_{2}$ values; $\mathrm{P} 25$ and P75: 25th and 75th percentile, respectively. For further abbreviations see legend to table 1 . 


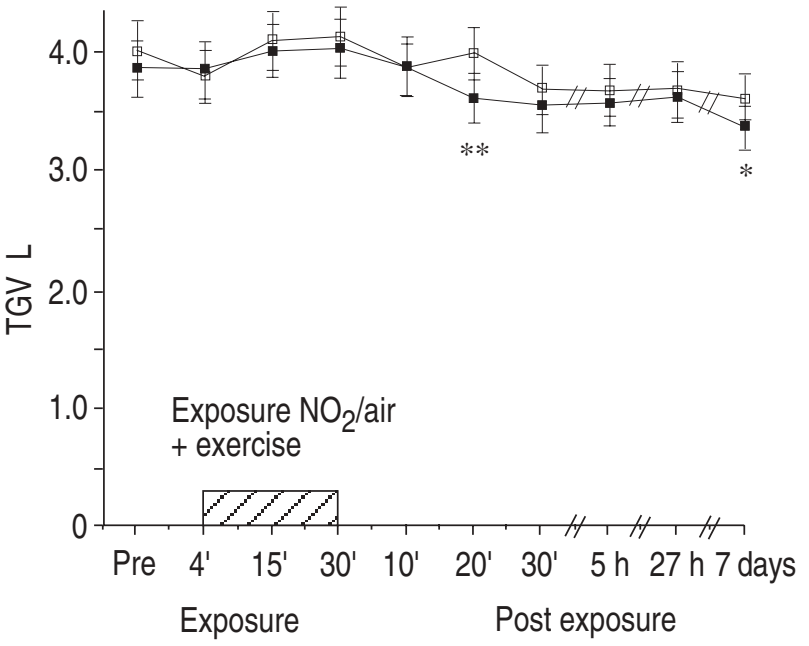

Fig. 4. - Thoracic gas volume (TGV). Changes during and after exposure to air or $\mathrm{NO}_{2}$. Values are presented as meantSEM. - $\square$ : TGV Air; — : TGV NO $\mathrm{NO}_{2}$ **: $\mathrm{p}=0.001 ; *: \mathrm{p}=0.02$.

\section{Subjective complaints}

When the subjects were interviewed during the exposure concerning subjective complaints, no difference between air and gas exposure could be detected except for a slightly increased smell of odour after $4 \mathrm{~min}$ of $\mathrm{NO}_{2}$ exposure (mean 2.26 vs 1.68 during air on a scale with range 1-7).

The questionnaire was answered by 18 out of 19 subjects and revealed no difference in subjective complaints within $24 \mathrm{~h}$ after exposure to air or $\mathrm{NO}_{2}$. During the week following exposure, seven subjects reported complaints after $\mathrm{NO}_{2}$ versus two after air. The symptoms after $\mathrm{NO}_{2}$ concerned increased sensitivity to irritants or exercise (four subjects), shortness of breath (2), rhinitis (1), headache (1) and hoarseness (1).

\section{Discussion}

This study showed a delayed increase in bronchial responsiveness to histamine, a small but persisting reduction in lung volume and an enhanced expression of a granulocyte adhesion protein after exposure to $\mathrm{NO}_{2}$ in subjects with asthma.

Bronchial hyperresponsiveness is a hallmark of asthma and the degree of hyperresponsiveness correlates with severity of disease [19]. Air pollutants, such as $\mathrm{NO}_{2}$, can enhance this responsiveness further and the duration of this increased responsiveness is of apparent interest, as a delayed effect may prolong the time when other agents can trigger asthma symptoms.

In our study, $\mathrm{NO}_{2}$ exposure tended to increase responsiveness to histamine $30 \mathrm{~min}$ after exposure. Some earlier studies have shown an increase in airway responsiveness in asthmatics immediately after $\mathrm{NO}_{2}$ exposure [1, 2], whilst, others have not $[3,4]$. In a recent meta-analysis of 20 studies on $\mathrm{NO}_{2}$ induced airway responsiveness in asthmatics, FolinsBeE [5] concluded that $\mathrm{NO}_{2}$ at concentrations of $200 \mu \mathrm{g} \cdot \mathrm{m}^{-3}$ and above increased airway responsiveness.

There was a significant delayed effect on bronchial responsiveness $5 \mathrm{~h}$ after exposure to $\mathrm{NO}_{2}$. As this delayed

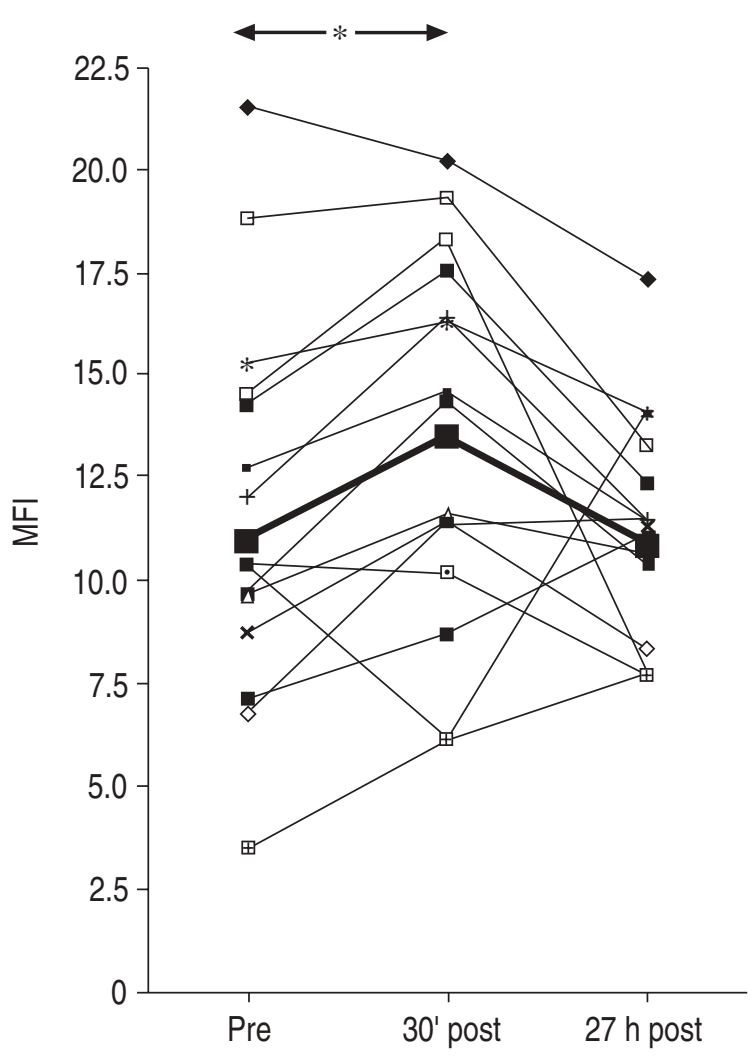

Fig. 5. - Changes in Mac-1 expression on granulocytes $(n=15)$. Mean fluorescence intensity (MFI) before, $30 \mathrm{~min}$ and $27 \mathrm{~h}$ after exposure to $488 \mu \mathrm{g} \mathrm{NO}_{2}$. Individual changes and mean values are presented. $\longrightarrow$ : mean. $*: \mathrm{p}=0.01$.

effect after $\mathrm{NO}_{2}$ has not been described previously, it is necessary to consider that factors other than $\mathrm{NO}_{2}$ might contribute to this result.

A difference in $s R$ aw at $5 \mathrm{~h}$, with a higher sRaw after $\mathrm{NO}_{2}$, could affect the result and cause an increased responsiveness. However, sRaw values following air and $\mathrm{NO}_{2}$ were virtually identical before histamine challenge at $5 \mathrm{~h}$.

Exposure to $\mathrm{NO}_{2}$ in ambient air during the study weeks was identical and low, according to personal monitoring both after $\mathrm{NO}_{2}$ and after air exposure, and interference of natural exposure with the results is, therefore, not likely.

Another possibility is that the change in responsiveness $5 \mathrm{~h}$ after exposure was caused by histamine inhaled at $30 \mathrm{~min}$ after exposure. However, repeated histamine inhalation challenges within a day in asthmatics have not been reported to change sensitivity to histamine [20, 21]. More important still, the effect of $\mathrm{NO}_{2}$ at $5 \mathrm{~h}$ is compared to that of sham exposure at the same time, which was also preceded by a histamine inhalation at 30 $\min$.

Exercise can reduce bronchial responsiveness to histamine for several hours $[20,22]$. In our study, a possible effect of the moderate exercise during exposure would be a decrease of bronchial responsiveness to histamine $5 \mathrm{~h}$ after exposure. However, the mean histamine threshold value at $5 \mathrm{~h}$ after sham exposure was not significantly different from that obtained at $30 \mathrm{~min}, 27 \mathrm{~h}$ and 7 days. When studying figure 2 , it may be argued that the difference after $5 \mathrm{~h}$ in PDsRaw, $100 \%$ between $\mathrm{NO}_{2}$ and 
air is caused mainly by a shift to the right of the air curve. However, the air curve does not significantly differ from the curve obtained at $30 \mathrm{~min}$. Even if it is presumed that exercise and/or histamine inhalation tends to shift the air curve to the right at $5 \mathrm{~h}$, this effect is apparently counteracted by $\mathrm{NO}_{2}$. To conclude, it is a real difference in bronchial responsiveness between $\mathrm{NO}_{2}$ and air at $5 \mathrm{~h}$. Lung volume was reduced about 5-10\% immediately after exposure to $\mathrm{NO}_{2}$, without any concomitant change in airway resistance, and this decrease persisted even 1 week after the exposure. However, this difference ought to be interpreted with caution, as TGV after sham exposure also tended to decrease.

The immediate effect of $\mathrm{NO}_{2}$ on lung volume has been investigated in many studies in asthmatics as well as in normals, and no effect has been reported [13, 23]. Delayed effects on lung function have seldom been looked for in short-term exposure studies, although the time-course of $\mathrm{NO}_{2}$ effects in gas accidents is characterized by a free interval lasting about $4-6 \mathrm{~h}$ followed by symptoms caused by increased microvascular permeability and oedema in the lung [6]. BeIL and Ulmer [24] exposed healthy subjects to $10,000 \mu \mathrm{g} \cdot \mathrm{m}^{-3} \mathrm{NO}_{2}$ for $14 \mathrm{~h}$ and found a slight increase in lung volume that had returned to pre-exposure values $10 \mathrm{~h}$ after the end of exposure.

In the current study, two histamine challenges were performed within a short time after the end of exposure, which might have influenced the lung volume measurements. No delayed effect on lung volume was, however, seen after sham exposure, which is in accordance with previous reports [20]. Even if histamine alone does not affect lung volume hours after inhalation it is still a possibility that $\mathrm{NO}_{2}$ exposure followed by repeated histamine inhalations gives another effect on lung volume than $\mathrm{NO}_{2}$ or histamine alone. A delayed effect on lung volume can, therefore, not be attributed with certainty to $\mathrm{NO}_{2}$ exposure alone based on this study.

We found an increased expression of the adhesion promoting glucoprotein Mac-1 (CR3 or CD11b/CD18) on granulocytes $30 \mathrm{~min}$ after exposure. Mac-1 is a glucoprotein essential for chemotaxis and adhesion to the endothelium of human neutrophils [25]. Mac-1 is partly stored in secretory granules, which are the most accessible intracellular compartment [26]. During antigen induced asthma, an increased expression of Mac-1 was observed [27], and an increased readiness to mobilize this receptor has been reported in children with asthma [28]. An enhanced expression of this granulocyte adhesion protein may indicate an increased capacity or tendency to penetrate the endothelial wall. An increased number of granulocytes has been reported in BAL after $\mathrm{NO}_{2}$ [29]. A small increase in adhesive capacity of the cell can also imply a priming of the granulocyte, being more easily activated when exposed to a subsequent stimuli.

The $\mathrm{NO}_{2}$ induced increase in bronchial responsiveness was small and within normal variability for most of the subjects. However, 3 out of 18 patients $(17 \%)$ increased their responsiveness substantially ( $>1$ doubling dose histamine). The effect of $\mathrm{NO}_{2}$ on histamine responsiveness in the laboratory makes it possible that $\mathrm{NO}_{2}$ could also increase susceptibility to nonspecific irritants, cold air and also to allergens in real life. Furthermore, the delayed effect seen in the majority of our subjects means that the time of increased susceptibility is longer than previously realized. $\mathrm{NO}_{2}$ exposure during rush hours in the morning could, therefore, facilitate triggering of asthma symptoms by other agents at least up to early afternoon. The reported subjective complaints during the week after exposure in our study might be an expression of this.

The clinical importance of these laboratory findings is supported by two recent epidemiological studies in Nordic cities showing that hospital admissions and emergency visits for asthma were significantly associated with ambient $\mathrm{NO}_{2}$ levels below guideline values [30, 31].

In conclusion, this study shows that short-term exposure to a relatively high ambient level of $\mathrm{NO}_{2}$ causes a delayed effect on bronchial responsiveness in asthmatics. This effect might be of clinical importance for at least a part of the population with asthma. The increased expression of an adhesion molecule in peripheral blood may indicate that $\mathrm{NO}_{2}$ exposure stimulates human granulocytes.

Acknowledgements: The authors thank nurse M. Claesson, physiology technician Kerstin Örnefalk and civil engineer M. Lorin for skilful technical assistance.

\section{References}

1. Bauer MA, Utell MJ, Morrow PE, Speers DM, Gibb FR. Inhalation of $0.30 \mathrm{ppm}$ nitrogen dioxide potentiates exercise-induced bronchospasm in asthmatics. Am Rev Respir Dis 1986; 134: 1203-1208.

2. Bylin G, Lindvall T, Rehn T, Sundin B. Effects of shortterm exposure to ambient nitrogen dioxide concentrations on human bronchial reactivity and lung function. Eur J Respir Dis 1985; 66: 205-217.

3. Hazucha MJ, Ginsberg JF, McDonell WF, et al. Assessment of $0.1 \mathrm{ppm}$ nitrogen dioxide effects on the airways of normal and asthmatic subjects. J Appl Physiol: Respirat Environ Exercise Physiol 1983; 54(3): 730-739.

4. Linn WS, Shamoo DA, L Avol EL, et al. Dose-response study of asthmatic volunteers exposed to nitrogen dioxide during intermittent exercise. Arch Environ Health 1986; 41: 292-296.

5. Folinsbee LJ. Does nitrogen dioxide exposure increase airways responsiveness? Toxicol Ind Health 1992; 8(5): 273-283.

6. Hajela R, Janigan DT, Landrigan P, Boudreau S, Sebastian S. Fatal pulmonary edema due to nitric acid fume inhalation in three pulp-mill workers. Chest 1990; 97: 487-489.

7. Rasmussen TR, Kjaergard SK, Tarp U, Pedersen OF. Delayed effects of $\mathrm{NO}_{2}$ exposure on alveolar permeability and glutathione peroxidase in healthy humans. Am Rev Respir Dis 1992; 146: 654-659.

8. Sandstrom T, Anderson MC, Kolmodin-Hedman B, Stjernberg N, Angstrom T. Bronchoalveolar mastocytosis and lymphocytosis after nitrogen dioxide exposure in man: a time-kinetics study. Eur Respir J 1990; 3: 138-143.

9. Cotes JE. In: Lung Function. Oxford, Blackwell Scientific Publ. 1979: pp. 384.

10. Du Bois AB, Bothelo SY, Bedell GN, Marshall R, Comroe JHJ. A rapid plethysmographic method for measuring thoracic gas volume: comparison with a nitrogen washout method for measuring functional residual capacity in normal subjects. J Clin Invest 1956; 35: 322-326. 
11. Du Bois AB, Bothelo SY, Comroe JHJ. A new method for measuring airway resistance in man using body plethysmograph: values in normal subjects and in patients with respiratory disease. J Clin Invest 1956; 35: 327.

12. Nieminen MM, Lahdensuo A, Kellomaeki L, Karvonen J, Muittari A. Methacholine bronchial challenge using a dosimeter with controlled tidal breathing. Thorax 1988; 43: 896-900.

13. Bylin G, Hedenstierna G, Lindvall T, Sundin B. Ambient nitrogen dioxide concentrations increase bronchial responsiveness in subjects with mild asthma. Eur Respir J 1988; 1: 606-612.

14. Peterson CGB, Enander I, Nystrand I, Anderson AS, Nilsson L, Venge P. Radioimmunoassay of human eosinophil cationic protein (ECP) by an improved method: establishment of normal levels in serum and turnover in vivo. Clin Exp Allergy 1991; 21: 561.

15. Olofsson I, Olsson I, Venge P. Serum myeloperoxidase and lactoferrin in neutropenia. Scand J Haematol 1977; 18: 73-80.

16. Hed J, Berg O, Forslid J, Halldén G, Lärka-Raffner G. The expression of CR1 and CR3 on nonmodulated and modulated granulocytes of healthy blood donors as measured by flow cytofluorometry. Scand J Immunol 1988; 28: 339-344.

17. Lundahl J, Halldén G, Hed J, Johansson SGO. A flow cytometric method to measure the stimulated mobilization and the intracellular pool of the adhesion promoting glucoprotein Mac-1. APMIS 1991; 99: 139-146.

18. Berglund M, Vahter M, Bylin G. Measurement of personal exposure to $\mathrm{NO}_{2}$ in Sweden: evaluation of a passive sampler. J Expo Anal Environ Epidemiol 1992; 2(3): 295-307.

19. Britton JR, Burney PGJ, Chinn S, Papacosta AO, Tattersfield AE. The relation between change in airway reactivity and change in respiratory symptoms and medication in a community study. Am Rev Respir Dis 1988; 138: $530-534$.
20. Hamielec C, Manning P, O'Byrne P. Exercise refractoriness after histamine inhalation in asthmatic subjects. Am Rev Respir Dis 1988; 138: 794-798.

21. Ruffin RE, Alpers JH, Crocket AJ, Hamilton R. Repeated histamine inhalation tests in asthmatic patients. J Allergy Clin Immunol 1981; 67(4): 285-289.

22. Schoeffel R, Anderson S, Gillam I, Lindsay D. Multiple exercise and histamine challenge in asthmatic patients. Thorax 1980; 35: 164-170.

23. Kerr HD, Kulle TJ, McIlhany ML, Swidersky P. Effects of nitrogen dioxide on pulmonary function in normal healthy humans and subjects with asthma and chronic bronchitis. Environ Res 1979; 19: 392-404.

24. Beil M, Ulmer WT. Wirkung von $\mathrm{NO}_{2}$ im MAK-Bereich auf Atemmechanik und bronchiale Acetylcholinempfindlichkeit bei Normalpersonen. Int Arch Occup Environ Health 1976; 38: 31-44.

25. Larson RS, Springer TA. Structure and function of leukocyte integrins. Immunol Rev 1990; 114: 181-217.

26. Sengel $\varnothing v$ H, Kjeldsen L, Borregaard N. Control of exocytosis in early neutrophil activation. Science 1993; 237: 1204-1206.

27. Arm JP, Walport MJ, Lee TH. Expression of complement receptors type 1 (CR1) and type 3 (CR3) on circulating granulocytes in experimentally provoked asthma. J Allergy Clin Immunol 1989; 83: 649-655.

28. Berends C, Hoekstra MO, Dijkhuizen B, de Monchy JGR, Gerritsen J, Kauffman HF. Expression of CD35 (CR1) and CD11b (CR3) on circulating neutrophils and eosinophils from allergic asthmatic children. Clin Exp Allergy 1993; 23: 926-933.

29. Helleday R, Sandström T, Stjernberg N. Differences in bronchoalveolar cell response to nitrogen dioxide exposure in nonsmokers. Eur Respir J 1994; 7: 1213-1220.

30. Pönke A. Asthma and low level air pollution in Helsinki. Arch Environ Health 1991; 46(5): 262-270.

31. Rossi OVJ, Kinnula VL, Tienari J, Huhti E. Association of severe asthma attacks with weather, pollen, and air pollutants. Thorax 1993; 48: 244-248. 